\title{
Saúde, Atenção Básica e Humanização: Práticas Humanizadas no Cotidiano de Trabalho de Agentes Comunitários de Saúde
}

\author{
Cunha, Larissa Santana; Nobre, Maria Teresa Lisboa \\ Universidade Federal de Sergipe — larissasc89@outlook.com
}

\begin{abstract}
Introdução: a partir da pesquisa intitulada "Saúde, Meio Ambiente e Cidadania: análise dos processos de adoecimento, produção de saúde, e práticas de resistência em contextos de degradação ambiental", realizada no decorrer dos anos de 2011 e 2012, o estudo se destina a descrever qualitativamente o cotidiano de trabalho de agentes comunitários de saúde (ACS), funcionários de determinada Unidade Básica de Saúde (UBS). o presente trabalho é desenvolvido sob diferente ótica, isto é, apesar de ter surgido por meio da pesquisa científica citada, aqui ele muda de foco, adquire nova roupagem, e difere a direção de seu olhar, o dirigindo para nova perspectiva: Quais as relações existentes entre o trabalho de agentes comunitários e humanização? de quais formas possíveis conseguimos captar as diretrizes da Política Nacional de Humanização (PNH) neste cotidiano, por sua vez árduo e por que não encantador? a fim de investigar tais questionamentos e fazer refletir sobre tamanhas inquietudes, faço uso da pesquisa em questão, pois a mesma teve como inserção de campo e para, além disso, também seu desenvolvimento, pautados no acompanhamento das atividades diárias desses profissionais. a relevância da investigação consiste na necessidade que temos de pensar, e analisar as maneiras pelas quais a humanização, e como chave-mestra a $\mathrm{PNH}$, age no dia-a-dia dos profissionais da saúde. Objetivos: o trabalho se destina a apresentar descrição e análise das possíveis relações existentes entre atenção primária (por meio do trabalho de ACS) e humanização, nos fazendo refletir sobre a efetividade e educação centrada na $\mathrm{PNH}$, e seus valiosos preceitos. Pretende investigar as formas pelas quais conseguimos reconhecer humanização nas práticas cotidianas, e nos locais onde a produção de saúde acontece, entendendo saúde não apenas enquanto ausência doença, ou apenas a partir da perspectiva biológica e orgânica. Metodologia: para o desenvolvimento da pesquisa foi utilizado o método etnográfico, baseado na inserção no campo, e acompanhado de diários de campo semanais, assim como também supervisões acadêmicas. As idas ao campo eram realizadas duas vezes por semana, onde acompanhávamos o trabalho dos agentes, assim como reuniões do Conselho Local de Saúde da localidade em questão, e demais atividades pontuais da UBS. Resultados: Conclui-se que a relação e o vínculo que se estabelece entre os agentes comunitários e a população atendida serve de grande exemplo quando falamos em humanização, e em concretização de uma política de humanização. Todavia, também pôde ser observada a carência de estudo sobre a PNH e suas inúmeras possibilidades e alcances oferecido pelo Estado, e por órgãos públicos. Conclusão: Os agentes comunitários de saúde parecem compreender a essência da humanização a partir de suas próprias vivências, e do vínculo surgido e preservado de forma natural com a população que os mesmos atendem.
\end{abstract}

Cunha, Larissa Santana; Nobre, Maria Teresa Lisboa. Saúde, Atenção Básica e Humanização: Práticas Humanizadas no Cotidiano de Trabalho de Agentes Comunitários de Saúde. In: Anais do Congresso Internacional de

Humanidades \& Humanização em Saúde [= Blucher Medical Proceedings, num.2, vol.1]. São Paulo: Editora Blucher, 2014. ISSN 2357-7282

DOI 10.5151/medpro-cihhs-10771 